\title{
Removal of Dyes Using Various Organic Peel-based Materials: A Systematic Review
}

\author{
Jitendra Kumar Sahoo 1,*(D), Amrutashree Hota ${ }^{1}$, Anil Kumar Khuntia ${ }^{1}$, Somakanta Sahu ${ }^{\text {, }}$, Shraban \\ Kumar Sahoo ${ }^{2}$ (D), Ashok Kumar Sabar ${ }^{1}$, Sidhant Kumar Pani ${ }^{1}$, Juhi Rath ${ }^{1}$ \\ 1 Department of Chemistry, School of Sciences, GIET University, Gunupur-765022, Rayagada, Odisha, India \\ 2 School of Applied Science, Centurion University of Technology and Management, Odisha, India \\ Correspondence: kumarjitu8093@gmail.com;
}

Scopus Author ID 57194462551

Received: 3.08.2021; Revised: 2.09.2021; Accepted: 5.09.2021; Published: 11.09.2021

\begin{abstract}
This review recapitulates the recent adsorption study literature regarding the activated biochar and nanocomposites of agricultural peel-based bio-adsorbents for the removal of dyes from wastewater. The use of agricultural peel in decoloration technology is promising for efficiency, costeffectiveness, and eco-friendliness. Various types of bio-adsorbents have been studied in the literature, such as orange peel, potato peel, banana peel, cucumber peel, Pomelo peel, and rambutan peel, respectively. The equilibrium data and kinetics were analyzed, and they fit known models are also summarized. This review article will help to know the applicability and potential of various peel-based bio-adsorbents in wastewater treatment. The conclusion has been drawn from the literature review, and few suggestions for further future studies are also proposed.
\end{abstract}

Keywords: peel-based bio-adsorbent; dyes; adsorption.

(C) 2021 by the authors. This article is an open-access article distributed under the terms and conditions of the Creative Commons Attribution (CC BY) license (https://creativecommons.org/licenses/by/4.0/).

\section{Introduction}

The current situation demonstrates the contamination of water as a major cause of increasing concern with fleet urbanization. The groundwater and surface water turn out to be contaminated as a result of agricultural discharges as well as untreated domestic and industrial wastes[1-3]. The prime components present in polluted wastewater are mostly organic chemicals like pesticides, fertilizers, dyes, and heavy metal ions, which arise from textiles, metallurgy, mining, tanning, chemicals, etc. Most of these pollutants are non-biodegradable, leading to further complications in the clean-up process[4,5].

The discharge of dyes into the surrounding territory is a reasonable source of eutrophication, aesthetic pollution, and disturbance in aquatic life. Several azo dyes and their degradation products, e.g., aromatic amines, are extremely carcinogenic[6] and pollute the watercourses[7-10]. These dyes are highly stable in the aquatic environment, and it becomes very difficult to take away those from water bodies [11]. This problem leads the way to an exhaustive search for the finest technology which could be employed to remove and decontaminate the dyes[12-15]. Furthermore, it treats industrial sewage, which is a vital goal for industries as well as environmental protection. Figure 1 illustrates various treatment processes such as, flocculation, filtration, ion exchange, chemical precipitation, adsorption, and membrane separation $[6,11]$ to remove these carcinogenic agents $[16,17]$ from contaminted water. 


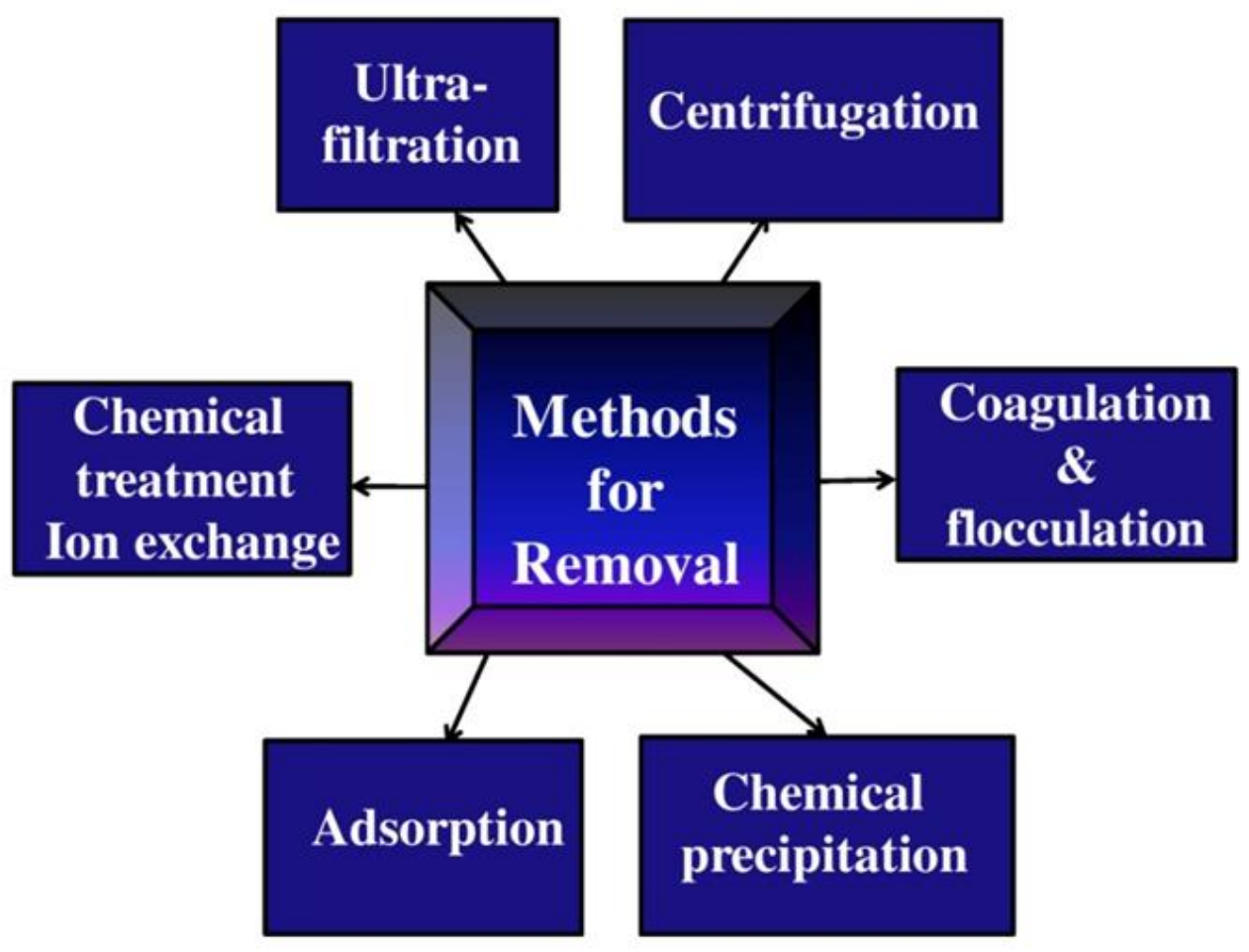

Figure 1. Various dye removal Methods.

When we consider the insufficient dye removal, sludge production, and cost, some limitations arise in the above treatment processes[15,18,19]. But among those, adsorption by natural adsorbents is proved to be highly proficient[20-22], and scientists notice. The merits of adsorption are subjected to remediation approaches like simplicity, efficiency, high selectivity, performance, cheap recovery of adsorbent and adsorbate, and efficient removal of pollutants[23]. In this case, activated carbon is a well-organized adsorbent for eliminating various types of carcinogenic dye pigments, though it is very high-priced. Hence, natural resources such as agriculture-based bio-adsorbents are more eye-catching as their effectiveness has been renowned well for different types of dye adsorption [13]. Different processes have been employed to modify adsorbents, which is very efficient in increasing adsorption [14].

Over the past few decades, there has been an increasing interest observed among scientists in the production of inexpensive and eco-friendly adsorbents for wastewater treatment. Recent researches reveal a number of low-cost adsorbents derived from agricultural ravage that are intensively investigated for the removal of dyes and heavy metals from wastewater[24].

Now, peels have given away their potential in the direction of being an eco-friendly and cost-effective bio-adsorbent material in working out the water contamination problem [25-29]. The agricultural wastes which are locally available are easily transformed to their respective carbonized (charcoal) forms, or activated carbons have been studied in this review.

\section{Classification of Dyes}

Generally, dye is a colored organic compound that unites itself over the surface or fabric to which it is applied. Most of the dyes are organic complexes and are also resistant to the action of detergent, soap, and the effect of temperature, sunlight, and atmospheric pressure[3032]. Synthetic dyes are broadly applied in many advanced technology fields $[26,33,34]$ like various textile, leather tanning, paper, food processing, rubber, cosmetics, plastics, dye 
manufacturing, printing, etc. These artificial dyes are also engaged in sewage, wastewater treatment and determining the cross-section area of activated sludge[35-37].

A huge number of outlets releasing water pollutants and various dyes is generated from the textile industry zone, which badly affects environmental conditions. So it is obligatory to employ effective management methods by using some unique adsorbents or other recent technologies to remove the blot of water by liberating them into water bodies. Commercial dyes can be classified in many ways, such as color, structure, and application methods[33]. On the other hand, so many complexities are found on considering the study of color and nomenclature. Therefore, classification according to application methods is mostly favorable. Furthermore, dyes are classified according to the charge on their particle when dissolved in an aqueous medium, i.e., anionic (acid, direct, reactive dyes), cationic (all the basic dyes), and dispersed or non-ionic dyes.

\subsection{Cationic dyes.}

The cationic dyes can be defined as the colored pigments which, when dissociated in an aqueous solution, split up into positively charged ions along with some complex ions[3840]. Furthermore, when they are applied on the surface of a fabric, they interact with those anionic groups present on the fabric's surface[41-43]. These cationic dyes are prepared based on basic (alkaline) dyes. The stained concept for cationic dye is that they color the fiber's surface by combining with anionic acidic groups in the 3rd monomeric form of acryl on, resulting in very high effectiveness andrapidity[44-48]. These dyes are generally used in coloring the leather, silk, cotton, paper, and ink manufacturing industries. Hence, the significance of these cationic dyes has greatly been increased to develop textile, synthetic fibers, paper, tanning, etc.

The important examples of cationic dyes are Astrazon red, Astrazon pink, Basic yellow, Basic orange, Basic red, Basic orange, Methylene blue, etc.[43,48-50]. These cationic dyes are very harmful to human health. Some of those may lead to Quadriplegia, Heinz body formation, increased heart rate, vomiting, cyanosis, jaundice, shock, and tissue necrosis in the case of human beings.

\subsection{Anionic dyes.}

Anionic dyes are also known as acid dyes which are water-soluble. These dyes contain acidic groups such as $\mathrm{COOH}$ and $\mathrm{SO}_{3} \mathrm{H}$, which, when applied on silk, wool, and nylon, an ionic bond is formed among protonated $\mathrm{NH}_{2}$ (fiber) and the acid group (dye)[51,52]. The acid leads to cation generation on the fabric surface, and the temperature substitutes the negative batch component of acid with the molecule of anionic or acid dye[53,54]. Acid dyes are usually applied to fabric material at a very low $\mathrm{pH}$. Various examples of anionic dye include Reactive Blue 4 (RB4), Acid Blue 25(AB25), Acid Yellow 36 (AY36), Acid Orange 7(AO7), Acid Orange 52 (AO52), Acid Red 151(AR151), Acid Blue 78 (AB78)[21,55].

Table 1. Advantages and disadvantages of Various dye removal methods.

\begin{tabular}{l|l|l} 
Methods & Advantages & Disadvantages \\
\hline $\begin{array}{l}\text { Adsorption by remaining /departed } \\
\text { bacterial biogas. }\end{array}$ & $\begin{array}{l}\text { Convinced dyes have a specific attraction } \\
\text { required with bacterial classes. }\end{array}$ & No operative for entirely dyes. \\
\hline Photochemical. & $\begin{array}{l}\text { No slush is formed, and obscene odors are } \\
\text { greatly condensed. }\end{array}$ & Developments of by-products. \\
\hline Particle exchange. & Renewal: No adsorptive damage. & Non-operative for entire dyes.
\end{tabular}




\begin{tabular}{|c|c|c|}
\hline Methods & Advantages & Disadvantages \\
\hline $\begin{array}{l}\text { Chemical behaviors. } \\
\text { Oxidative procedure. }\end{array}$ & Easiness of submission. & $\begin{array}{l}\left(\mathrm{H}_{2} \mathrm{O}_{2}\right) \text { agents need to stimulate by roughly } \\
\text { resources slush group. }\end{array}$ \\
\hline Irradiation. & Operative corrosion at lab measure. & Involves many liquified $\mathrm{O}_{2}$ \\
\hline Mixed bacterial cultures. & Decolorized in $24-30$ hours. & $\begin{array}{l}\text { Below aerobic surroundings, azo dyes are } \\
\text { not eagerly absorbed. }\end{array}$ \\
\hline Membrane separation. & Eliminates dye kinds entirely. & Intense slush manufacture. \\
\hline $\begin{array}{l}\text { Biotic behaviors pale by silver-rot } \\
\text { yeasts. }\end{array}$ & $\begin{array}{l}\text { Silver-rot yeasts are capable of reducing dyes } \\
\text { with } \mathrm{S} \text { incentives. }\end{array}$ & $\begin{array}{l}\text { Incentive manufacture has similarly been } \\
\text { exposed to be undependable. }\end{array}$ \\
\hline $\begin{array}{l}\text { Anaerobic fabric- dyes bio-treatment } \\
\text { arrangements. }\end{array}$ & $\begin{array}{l}\text { Permit azo and extra aquatic- miscible dyes } \\
\text { to be bleached. }\end{array}$ & $\begin{array}{l}\text { Anaerobiotic collapse produces methane and } \\
\text { hydrogen sulfides. }\end{array}$ \\
\hline $\begin{array}{l}\text { Sodium hypo chloride } \\
(\mathrm{NaOCl})\end{array}$ & Pledges and hurries azo bond breaking. & Production of aromatic amines. \\
\hline Electro-kinetic coagulation. & Economically possible. & High slush manufacture. \\
\hline $\begin{array}{l}\text { Physical behaviors Adsorption by } \\
\text { stimulated carbon. }\end{array}$ & Decent exclusion of inclusive different dyes. & Identical exclusive. \\
\hline Electrochemical devastation. & $\begin{array}{l}\text { No ingesting of chemical and no slush } \\
\text { accumulation. }\end{array}$ & $\begin{array}{l}\text { Comparatively, increased current charges } \\
\text { reason a straight reduction in dye exclusion. }\end{array}$ \\
\hline
\end{tabular}

\subsection{Non-ionic dyes.}

Non-ionic or dispersed dyes are characterized by sulfide and anthraquinone composite structures having $-\mathrm{NH},-\mathrm{C}=\mathrm{O}$, and aromatic groups. Reactive dyes are more stable as compared to dispersed dyes due to the presence of azo dyes. These dyes possess very low solubility in water. These are mainly used for the pigmentation of polyester fiber surfaces. Some examples are Disperse Yellow 3(DY3), Disperse Blue 3(DB3), Disperse Orange 13(DO13), Disperse Yellow 54(DY54), Disperse Red 54(DR54), etc.

\section{Dye Removal Methods}

An enduring, efficient and sustainable dye removal method must be established to eliminate the major issue of sewage water treatment. Before release, dye contaminated water should be purified first to minimize its carcinogenic effect on the surroundings. Hence, the existing research for the dye removal techniques is extended to three types of biological, chemical, and physical methods. Though there are numerously tested and tried methods to carry out dye removal, most methods show a common demerit, i.e., secondary pollutant generation towards the environment.

The biological method is a typical technique that is used extensively in several countries for wastewater treatment[56-58]. Generally, it is a conventional method that includes a permutation of the aerobic and anaerobic processes $[59,60]$. This combined process is very cheap in the case and can be easily accomplished. Various biological methods include dye removal by Fenton reaction, Ozonation, Oxidation, Ultraviolet, and Photochemical irradiation (Figure 1).

Commercially, the processes of chemical dye removal are very ill-favored and require précised equipment as well as a high amount of electrical energy. This process also has a demerit, i.e., large-scale chemical consumption is needed, which leads to the origination of secondary pollution at the end of the removal process[61].

A mass transfer mechanism commonly accomplishes physical methods for dye removal. Various physical dye removal methods include coagulation or flocculation, irradiation, ion-exchange, adsorption, membrane filtration, reverse osmosis, and nano/ultrafiltration[62]. These are very simple and cost-effective methods and require the least 
amount of chemicals compared to biological and chemical methods. It is considered more predictable as it does not deal with living organisms[63].

Furthermore, in the midst of all physicochemical methods, the most approved and favorable ones are flocculation, adsorption united through ozonation, electro-kinetic process, flotation, ion exchange, coagulation, oxidation, membrane filtration, and precipitation[22,64,65]. But there are some limitations observed for these processes such as (i) in ozonation process, the half-life is very brief (ii) in case of ion-exchange process essential renewal, and removal ability is needed (iii) in the process of coagulation, manufacturing of huge particles as well as high slush is required (iv) in the oxidation process, production of energy outlets and huge particles are needed $(\mathrm{v})$ in the filtration process, manufacturing of concentrated slush is required. Therefore, adsorption has been well-fit for removing dyes from sewage water as it is cost-effective, eco-friendly, and efficient. Table.1 shows the various dye removal methods with their merits and demerits.

\section{Bio-Sorption Models}

To develop an accurate and effective model for the adsorption of polluting agents such as dyes present in aqueous media, adsorption thermodynamic, kinetics, and equilibrium studies are needed. Adsorption isotherm study is one of the very useful tools for giving information about $\mathrm{q}_{\max }$ and feasible interactions between adsorbate and adsorbent surfaces. When someone considers the adsorption isotherms, the major isotherms used in the batch adsorption process are Langmuir[66] and Freundlich models, which describe the monolayer and heterogeneous surface, respectively, with linear and non-linear expressions. Furthermore, kinetic studies are mostly used to predict optimum conditions[67] batch adsorption techniques in full scale. The kinetic study infers about adsorption mechanisms[15,68] and possible rate-controlling steps such as chemical reaction methods or mass transport. Several kinetic models include pseudofirst-order and pseudo-second-order, Elovich, and Weber-Moris. The most established kinetic models are pseudo-first and pseudo-second-order kinetic models [68]. When we consider the thermodynamic studies, we infer that these are used to determine the adsorption, the adsorbent nature, spontaneity, and adsorbate at equilibrium conditions [66]. Also, thermodynamic studies provide information on whether the reaction is favorable or unfavorable by determining the temperature range $[69,70]$. The main thermodynamic parameters are change of Gibbs energy $\left(\Delta \mathrm{G}^{\mathrm{o}}\right)$, adsorption enthalpy $\left(\Delta \mathrm{H}^{\mathrm{o}}\right)$, and entropy $\left(\Delta \mathrm{S}^{\mathrm{o}}\right)$. Those parameters can be calculated by fitting data obtained by adsorption experiments at different temperatures [63].

\section{Agricultural Peels for Dye Adsorption}

In this section, all published adsorption results regarding the dyes treatment by various agricultural peels are presented. The basic categories of dyes are discussed in detail. The isotherm model, kinetic model, maximum uptake capacity $\left(\mathrm{q}_{\max }\right)$, optimum $\mathrm{pH}$, and contact time are tabulated in Table 2. The detailed study of various isotherm and kinetic models were very limited in almost all the reported articles but most of the authors fitting Langmuir or Freundlich in isotherm and pseudo-first-order and pseudo-second-order in the kinetic model.

\subsection{Potato peel.}

Samarghandy et al. (2011) [71] studied the removal of reactive black 5 using acidmodified bio-mass of potato peel waste. Various adsorption, isotherm, and kinetic studies were 
performed in this experiment. The experiment was well-fitted for Langmuir adsorption isotherm and pseudo-first-order kinetics with a percentage removal of $85.5 \%$.

Gupta et al. (2011)[72] studied the adsorption of MB and MG from wastewater using potato peel biomass. The experiment was well-defined by pseudo-first-order kinetics and Freundlich adsorption isotherm. The various batch equilibrium experiments were also performed along with the thermodynamic parameters.

Malekl et al. (2013)[73] investigated the efficiency of potato peel towards the removal of reactive red 198. The experiment was well-established for Langmuir adsorption isotherm with a capacity $93 \mathrm{mg} / \mathrm{g}$. Various batch adsorptions have also performed to this extent, such as $\mathrm{pH}=11$ and contact time $150 \mathrm{~min}$.

\subsubsection{Adsorbent preparation.}

Potato peels were collected and dried for 5-7 days at room temperature. Then the dried peels were carbonized with $0.01 \mathrm{M} \mathrm{HCl}$ modification at $90{ }^{\circ} \mathrm{C}(24 \mathrm{~h})$. Then the carbonized biomass was crushed to 40-45 mesh size[71].

Potato peels were dried at $60^{\circ} \mathrm{C}(45 \mathrm{~min})$, and carbonized potato peel bio-mass was ground to 100-150 mm size. The $\mathrm{pH}$ was neutralized at 7 throughout the experiment[72].

Potato peel bio-mass adsorbent was prepared by carbonizing it at $170^{\circ} \mathrm{C}$ for $(24 \mathrm{~h})$ and then modifying it with $\mathrm{H}_{2} \mathrm{SO}_{4}$ and $\mathrm{NaOH}$. Then again carbonized at $70^{\circ} \mathrm{C}(48 \mathrm{~h})$ and crushed to 225-575 $\mu \mathrm{m}$ in size[73].

\subsection{Banana peel.}

Moubarak et al.[74] investigated the removal of MB using the powered form of banana peel. They studied the batch adsorption equilibrium processes such as temperature, contact time, agitation, $\mathrm{pH}$, and adsorbent dosage. The contact time was found to be $40 \mathrm{~min}$, and the removal efficiency was observed to be $90 \%$. The experiment was well-established for Langmuir adsorption isotherm.

Amel et al. (2012) and Liu (2014)[75,76] reported the adsorption of MB using the nanocomposite of banana peel at $\mathrm{pH}=8$; the activated banana peel shows a maximum adsorption capacity of $19.671 \mathrm{mg} / \mathrm{g}$. The experiment was well-suited for Langmuir adsorption kinetics and pseudo-second-order rate equation.

Pishgar et al. (2013) [77]studied the removal of basic blue 159 (BB159) from an aqueous solution using activated biochar of banana peel. The experiment was well-fitted to pseudo-second-order kinetics and Freundlich adsorption isotherm. Batch equilibrium conditions were as $\mathrm{pH}=9,0.4 \mathrm{~g}$ adsorbent dosage, $200 \mathrm{rpm}$, and contact time $60 \mathrm{~min}$.

\subsubsection{Adsorbent preparation.}

The adsorbent was washed with distilled water to remove dirt content. Then it was dried at $105^{\circ} \mathrm{C}$. The carbonized form was sieved to $0.315 \mathrm{~mm}$ in size. Then it was mixed with $\mathrm{NaOH}$ $(0.1 \mathrm{M})$ with a ratio of $1: 5$ and again carbonized and sieved to the same size[76].

\subsection{Rambutan peel.}

Ahmad et al. (2011) [78] adsorbed the malachite green (MG) using the bio-adsorbent of Rambutan peel. The experiment for activated carbon of Rambutan peel (RPAC) was carried 
out under different batch equilibrium conditions. The experiment was well-suited for Freundlich adsorption isotherm as well as pseudo-second-order kinetics.

In 2012, Alrozi et al. [79] studied the removal of Remazol Brilliant Blue R (RBBR) dye using the nano-structure of Rambutan peel. The batch adsorption conditions were observed to be at $\mathrm{pH}$ 2-12 and dosage 0.05-1.2. The equilibrium was well-established by Langmuir adsorption isotherm with $\mathrm{q}_{\max }$ value $112.69 \mathrm{mg} / \mathrm{g}$. And the batch adsorption was followed by pseudo-second-order kinetics with a good correlation.

Another researcher, Njoku et al. (2014) [80], investigated the removal of acid yellow 17 (AY17) using a novel nanosheet of Rambutan peel. To this extent, the adsorbent was prepared by modifying the activated carbon with $\mathrm{KOH}$ as a precursor. The adsorption capacity was studied under different batch conditions such as $\mathrm{pH}$, contact time, adsorbent dosage, etc. The experiment followed Langmuir adsorption isotherm and pseudo-second-order kinetics with $\mathrm{q}_{\max }$ value $215.05 \mathrm{mg} / \mathrm{g}$.

\subsubsection{Adsorbent preparation.}

Firstly, the Rambutan peel was washed and dried at $378 \mathrm{~K}(24 \mathrm{~h})$ for the removal of moisture. The carbonized Rambutan peels were crushed to the size of 1-2 mm. The biochar was mixed with $\mathrm{KOH}$ at a ratio 1:2.9. Distilled water was added to the composite to dissolve the $\mathrm{KOH}$ pellets. Then the mixture was dehydrated at $378 \mathrm{~K}(24 \mathrm{~h})$ to remove out the moisture. $0.1 \mathrm{M} \mathrm{HCl}$ was added until the $\mathrm{pH}$ reached 6.5-7[78].

The collected Rambutan seed materials were cleaned with boiled water and deionized water to remove any adhering dirt. Then it was dried in the oven at $60^{\circ} \mathrm{C}(24 \mathrm{~h})$. Then the carbonized Rambutan peel was ground and sieved to obtain $250-355 \mu \mathrm{m}$ particle size[79].

The RP was rinsed with distilled water and carbonized in the oven at $105^{\circ} \mathrm{C}(24 \mathrm{~h})$ to remove moisture content. The carbonized sample was crushed to a size of $0.5-1.0 \mathrm{~mm}$. The inert atmosphere was continuously maintained by passing nitrogen $(99.99 \%)$ through the system (during the heating $\left(150 \mathrm{~cm}^{3} \mathrm{~min}^{-1}\right)$ and cool-down intervals $\left.\left(100 \mathrm{~cm}^{3} \mathrm{~min}^{-1}\right)\right)[80]$.

\subsection{Cucumber peel.}

Akkay and Guzel (2014) [81] studied the efficiency of cucumber peel (CP) for the bioadsorption of methylene blue (MB) dye from wastewater. They also compared the removal of methylene blue (MB) on Parsley stalks (PS) and watermelon seed hull (WSH). The adsorption of MB was inferred in the batch condition of $\mathrm{pH}(2-10)$, temperature (293-333K), initial dye concentration $(25-450 \mathrm{mg} / \mathrm{L})$, ionic strength $(0.0-1.0 \mathrm{~mol} / \mathrm{L} \mathrm{NaCl})$. The adsorption capacity of CP, PS, and WSH was reported to be $111.11,400$ and $57.14 \mathrm{mg} / \mathrm{g}$ at $\mathrm{pH}_{\mathrm{zpc}} 6.42,6.26$, and 6.83, respectively. The experiment was well-fitted to Langmuir adsorption isotherm followed by pseudo-second-order kinetics for PS and pseudo-first-order kinetics for CP and WSH. In this experiment, the desorption ability and effectiveness of the adsorbent were also enhanced by treating with $\mathrm{HCl}$ and $\mathrm{H}_{3} \mathrm{PO}_{4}$.

\subsubsection{Adsorbent preparation.}

In this experiment, a nano-structural bio-adsorbent of cucumber peel was prepared. The bio-adsorbents were rinsed with deionized water. Then it was dried at $70^{\circ} \mathrm{C}(24 \mathrm{~h})$ for carbonization. The carbonized form was ground to $500 \mathrm{~mm}$ size and used as a nanocomposite to remove MB dye[81]. 


\subsection{Pomelo peel.}

Jayranjan et al. (2011)[82] studied the removal of Congo Red (CR) using Pomelo fruit peel as bio-adsorbent. The experiment was carried out using batch adsorption conditions such as $\mathrm{pH}(5.99-8.73)$, temperature $\left(30^{0}-60^{\circ} \mathrm{C}\right)$, and adsorbent dosage of $1.0-3.0 \mathrm{gL}^{-1}$. The Pomelo peel bio-adsorbent experiment was well-suited for Langmuir adsorption isotherm with an adsorption capacity of 1.08 to $0.75 \mathrm{mg} / \mathrm{g}$.

Furthermore, in 2014, Argun et al.[83] investigated the adsorption of reactive blue 114 (RB114) from wastewater using Pomelo nano-porous composite as bio-adsorbent. The batch equilibrium was carried out with conditions such as $\mathrm{pH}=2$, temperature $=303 \mathrm{~K}$, and the contact time $=90 \mathrm{~min}$. The experiment was well-explained by Langmuir adsorption isotherm with $\mathrm{q}_{\max }$ value $16 \mathrm{mg} / \mathrm{g}$.

\subsubsection{Adsorbent preparation.}

The Pomelo peels were washed with distilled water and air-dried in the oven at $40^{\circ} \mathrm{C}$ (48h). The carbonized peel was ground up to $0.840 \mathrm{~m} / \mathrm{m}$ in size. The $\mathrm{pH}$ of the adsorbent was adjusted by a small amount of $0.1 \mathrm{M} \mathrm{HCl}$ or $\mathrm{NaOH}[82]$.

Collected Pomelo peels were cleaned using distilled water to remove the interference effect of external dirt. The washed peels were cut into tiny pieces up to $0.5-1.0 \mathrm{~cm}$. then it was carbonized (after drying in the sun for $4-5$ days) at $60.8^{0} \mathrm{C}(48 \mathrm{~h})$. The resulting carbonized form was crushed up to a particle size of $500 \mathrm{~mm}$ for the adsorption experiment[83].

\subsection{Orange peel.}

EI-Said et al. (2013) [84]considered orange peel to remove direct red 79 and direct yellow 27 from wastewater. The batch adsorption was carried out by investigating $\mathrm{pH}$, the ratio of solid/liquid, initial dye concentration, and contact time. The experiment followed Freundlich adsorption isotherm and pseudo-second-order kinetics.

Khafuoui et al. (2014)[85] investigated the adsorption of MB using orange peel bioadsorbent. They also studied the temperature dependence on adsorption and inferred that with increasing temperature, adsorption capacity increases. The experiment followed Langmuir adsorption isotherm with $\mathrm{q}_{\max }$ value $9.74 \mathrm{mg} / \mathrm{g}$ and pseudo-second-order kinetics.

Ahmed et al. (2012) studied the adsorption of reactive blue 19 (RB19) using modified orange peel. The experiment was carried by reporting various batch equilibrium studies. The experiment was well-established for Freundlich adsorption isotherm and pseudo-first-order kinetics[86].

Table 2. List of isotherm, maximum adsorption capacity, optimum $\mathrm{pH} / \mathrm{time}$, and kinetic models for describing the removal of heavy metals on RH-based adsorbent.

\begin{tabular}{l|l|l|l|l|l|l}
$\begin{array}{l}\text { Peel-based bio- } \\
\text { adsorbent }\end{array}$ & Dye Adsorbed & $\begin{array}{l}\text { Isotherm } \\
\text { Model }\end{array}$ & $\mathbf{q} \max (\mathbf{m g} / \mathbf{g})$ & $\begin{array}{l}\text { Kinetic } \\
\text { Model }\end{array}$ & $\begin{array}{l}\text { Optimum } \\
\mathbf{p H} / \text { Time }\end{array}$ & Reference \\
\hline Orange Peel & Reactive Blue19 & $\begin{array}{l}\text { Langmuir, } \\
\text { Temkin }\end{array}$ & 45.5 & $\begin{array}{l}\text { Pseudo } \\
\text { First } \\
\text { order }\end{array}$ & $4 / 120$ min & Ahmed et al. 2012 \\
\hline $\begin{array}{l}\text { Modified with NaOH } \\
\text { orange peel }\end{array}$ & Reactive Blue 19 & $\begin{array}{l}\text { Langmuir, } \\
\text { Temkin }\end{array}$ & 25.0 & $\begin{array}{l}\text { Pseudo } \\
\text { First } \\
\text { order }\end{array}$ & $4 / 120$ min & Ahmed et al. 2012 \\
\hline Orange Peel & Direct Red 79 & $\begin{array}{l}\text { Langmuir, } \\
\text { Freundlich }\end{array}$ & 151.50 & $\begin{array}{l}\text { Pseudo } \\
\text { Second } \\
\text { order }\end{array}$ & $3 / 60$ min & Mansour et al. 2012
\end{tabular}




\begin{tabular}{|c|c|c|c|c|c|c|}
\hline $\begin{array}{l}\text { Peel-based } \quad \text { bio- } \\
\text { adsorbent }\end{array}$ & Dye Adsorbed & $\begin{array}{l}\text { Isotherm } \\
\text { Model }\end{array}$ & $q_{\max }(\mathrm{mg} / \mathrm{g})$ & $\begin{array}{l}\text { Kinetic } \\
\text { Model }\end{array}$ & $\begin{array}{l}\text { Optimum } \\
\text { pH/Time }\end{array}$ & Reference \\
\hline Orange Peel & Direct Yellow 27 & $\begin{array}{l}\text { Langmuir, } \\
\text { Freundlich }\end{array}$ & 153.85 & $\begin{array}{l}\text { Pseudo } \\
\text { Second } \\
\text { order }\end{array}$ & $3 / 60 \min$ & Mansour et al. 2012 \\
\hline Potato Peel & $\begin{array}{l}\text { Methylene } \\
\text { blue }\end{array}$ & Langmuir & 33.55 & $\begin{array}{l}\text { Pseudo } \\
\text { Second } \\
\text { order }\end{array}$ & $8 / 60 \mathrm{~min}$ & Oktem et al. 2012 \\
\hline $\begin{array}{l}\text { HCL treated Potato } \\
\text { Peel }\end{array}$ & Reactive Black 5 & Langmuir & 3.61 & $\begin{array}{l}\text { Pseudo } \\
\text { Second } \\
\text { order }\end{array}$ & $3 / 120 \mathrm{~min}$ & Samarghandy et al. 2011 \\
\hline Banana Peel & Basic Blue 119 & - & - & $\begin{array}{l}\text { Pseudo } \\
\text { Second } \\
\text { order }\end{array}$ & $9 / 60 \min$ & Pishgar et al. 2013 \\
\hline $\begin{array}{l}\text { Banana Peel } \\
\text { Activated Carbon }\end{array}$ & $\begin{array}{l}\text { color from palm } \\
\text { oil mill effluent }\end{array}$ & $\begin{array}{l}\text { Redlich- } \\
\text { Peterson }\end{array}$ & 135.14 & $\begin{array}{l}\text { Pseudo } \\
\text { Second } \\
\text { order }\end{array}$ & $2 / 30$ hour & Mohammed et al. 2014 \\
\hline Pomelo Peel & Reactive Blue 114 & Langmuir & 16.3 & $\begin{array}{l}\text { Pseudo } \\
\text { Second } \\
\text { order }\end{array}$ & $2-11 / 90$ & Argun et al., 2014 \\
\hline $\begin{array}{l}\text { Activated carbon } \\
\text { from Rambutan Peel }\end{array}$ & Malachite Green & Freundlich & 329.49 & $\begin{array}{l}\text { Pseudo } \\
\text { Second } \\
\text { order }\end{array}$ & $8 / 2-3$ hour & Ahmad, et al., 2011 \\
\hline Cucumber Peel & Methylene Blue & Langmuir & 111.11 & $\begin{array}{l}\text { Pseudo } \\
\text { First } \\
\text { order }\end{array}$ & $7-10 /-$ & Akkaya, et al. 2014 \\
\hline
\end{tabular}

\subsubsection{Adsorbent preparation.}

Orange peels were collected and washed with distilled water. It was carbonized at $150^{\circ} \mathrm{C}(36 \mathrm{~h})$ and sieved to a particle size of $3.35 \mathrm{~mm}[84]$.

The orange peel was collected, washed with distilled water. It was dried at $105^{\circ} \mathrm{C}(24 \mathrm{~h})$ and carbonized at $550^{\circ} \mathrm{C}(2 \mathrm{~h})$. The carbonized OP was crushed to form $0.315 \mathrm{~mm}$ in size[85].

Orange peel was washed and carbonized at $70^{\circ} \mathrm{C}(24 \mathrm{~h})$. Then it was modified with $1 \mathrm{~L}$ $\mathrm{NaOH}$ for $24 \mathrm{~h}$. After decantation and filtration, the $\mathrm{pH}$ was balanced to 7.0 by washing with distilled water[86].

\section{Conclusion}

In this review literature, the application of agricultural peel wastes as bio-adsorbents for the adsorption of various dyes was discussed. The $\mathrm{pH}$ of the solution was affecting the adsorption process very strongly, and the conclusion depends upon the "nature" (basic/ cationic or acid/reactive) of organic dyes and the charge contained by the adsorbents (functional groups and $\mathrm{pHpzc}$ ). According to the classification of maximum adsorption ability for monolayer, agricultural peels give a high value of $\mathrm{q}_{\mathrm{m}}$, showing their greater potential for adsorption. Most of the experimental conditions were well-established by Langmuir adsorption isotherm and Pseudo-second order kinetics. Thermodynamic studies were evaluated and carefully discussed to eliminate possible flaws. This review literature infers that a more detailed and systematic study is needed to decontaminate wastewater using peel-based bio-adsorbent.

\section{Future Scope}

After cautious contemplations on variously described review objectives for removing carcinogenic dyes contaminants in the past few decades, this systematic review also predicted 
a small number of research gaps for further exhaustive and comprehensive studies and technological development, which are necessary for current systems. So various recommendations for future scope are discussed below in major cases of review analysis. The appliance of untreated solid bio-wastes as adsorbents can lead to the production of many organic compounds. These organic compounds which are leached in the experimental analysis must be studied carefully; otherwise, it may infer some invalid results. Till now, the adsorption processes are at the step of laboratory-scale batch studies. So furthermore, a study is needed in this area to stretch its extent up to an industrial scale by designing various techniques. Mostly the research methodologies are focused on the adsorptive efficiency of the adsorbent materials. But more study is needed on the sustainable valorization of post-sorption materials, which could be taken as the alternative for chemical products like catalysts, fertilizers, feed additives, etc. A reasonable study on more cost-effectiveness of bio-adsorbent for wastewater management must be carried out for practical use on an industrial scale.

\section{Funding}

This research received no external funding.

\section{Acknowledgments}

This review has no acknowledgment.

\section{Conflicts of Interest}

The authors declare no conflict of interest. The funders had no role in the study's design, in the collection, analyses, or interpretation of data, in the writing of the manuscript, or in the decision to publish the results.

\section{References}

1. Al-Degs, Y.; Khraisheh, M.A.M.; Allen, S.J.; Ahmad, M.N.; Walker, G.M. Competitive adsorption of reactive dyes from solution: Equilibrium isotherm studies in single and multisolute systems. Chem. Eng. J.2007, 128, 163-167, https://doi.org/10.1016/j.cej.2006.10.009.

2. Ventura-Camargo, B.D.C.; Marin-morales, M.A. Azo Dyes: Characterization and Toxicity- A Review. Text. Light Ind. Sci. Technol.2013.

3. Banat, I.M.; Nigam, P.; Singh, D.; Marchant, R. Microbial decolorization of textile-dye-containing effluents: A review. Bioresour. Technol.1996, 58, 217-227, https://doi.org/10.1016/S0960-8524(96)00113-7.

4. Chiou, M.S.; Ho, P.Y.; Li, H.Y. Adsorption of anionic dyes in acid solutions using chemically cross-linked chitosan beads. Dye. Pigment. 2004, 60, 69-84, https://doi.org/10.1016/S0143-7208(03)00140-2.

5. Crini, G. Non-conventional low-cost adsorbents for dye removal: A review. Bioresour. Technol.2006, 97, 1061-1085, https://doi.org/10.1016/j.biortech.2005.05.001.

6. Wang, H.; Xu, J.; Liu, X.; Sheng, L. Preparation of straw activated carbon and its application in wastewater treatment: A review. J. Clean. Prod.2021, 283, https://doi.org/10.1016/j.jclepro.2020.124671.

7. Demirbas, A. Agricultural based activated carbons for the removal of dyes from aqueous solutions: A review. J. Hazard. Mater.2009, 167, 1-9, https://doi.org/10.1016/j.jhazmat.2008.12.114.

8. Dinçer, A.R.; Güneş, Y.; Karakaya, N.; Güneș, E. Comparison of activated carbon and bottom ash for removal of reactive dye from aqueous solution. Bioresour. Technol.2007, 98, 834-839, https://doi.org/10.1016/j.biortech.2006.03.009.

9. Ferreira, A.M.; Coutinho, J.A.P.; Fernandes, A.M.; Freire, M.G. Complete removal of textile dyes from aqueous media using ionic-liquid-based aqueous two-phase systems. Sep. Purif. Technol.2014, 128, 58-66, https://doi.org/10.1016/j.seppur.2014.02.036.

10. Kyzas, G.Z.; Fu, J.; Matis, K.A. The change from past to future for adsorbent materials in treatment of dyeing wastewaters. Materials (Basel).2013, 6, 5131-5158, https://doi.org/10.3390/ma6115131.

11. Shamsollahi, Z.; Partovinia, A. Recent advances on pollutants removal by rice husk as a bio-based adsorbent: A critical review. J. Environ. Manage.2019, 246, 314-323, https://doi.org/10.1016/j.jenvman.2019.05.145. 
12. Forgacs, E.; Cserháti, T.; Oros, G. Removal of synthetic dyes from wastewaters: A review. Environ. Int. 2004, 30, 953-971, https://doi.org/10.1016/j.envint.2004.02.001.

13. Gupta, V.K.; Suhas. Application of low-cost adsorbents for dye removal - A review. J. Environ. Manage.2009, 90, 2313-2342, https://doi.org/10.1016/j.jenvman.2008.11.017.

14. Kadirvelu, K.; Kavipriya, M.; Karthika, C.; Radhika, M.; Vennilamani, N.; Pattabhi, S. Utilization of various agricultural wastes for activated carbon preparation and application for the removal of dyes and metal ions from aqueous solutions. Bioresour. Technol.2003, 87, 129-132, https://doi.org/10.1016/S09608524(02)00201-8.

15. Kyzas, G.Z.; Kostoglou, M. Green adsorbents for wastewaters: A critical review. Materials (Basel)2014, 7, 333-364, https://doi.org/10.3390/ma7010333.

16. Lee, J.W.; Choi, S.P.; Thiruvenkatachari, R.; Shim, W.G.; Moon, H. Evaluation of the performance of adsorption and coagulation processes for the maximum removal of reactive dyes. Dye. Pigment.2006, 69, 196-203, https://doi.org/10.1016/j.dyepig.2005.03.008.

17. Malik, R.; Ramteke, D.S.; Wate, S.R. Adsorption of malachite green on groundnut shell waste based powdered activated carbon. Waste Manag. 2007, 27, https://doi.org/10.1016/j.wasman.2006.06.009.

18. Carnaje, N.P.; Talagon, R.B.; Peralta, J.P.; Shah, K.; Paz-Ferreiro, J. Development and characterisation of charcoal briquettes from water hyacinth (Eichhornia crassipes)-molasses blend. PLoS One 2018, 13, 1-14, https://doi.org/10.1371/journal.pone.0207135.

19. Mohan, S. V.; Bhaskar, Y. V.; Karthikeyan, J. Biological decolourisation of simulated azo dye in aqueous phase by algae Spirogyra species. Int. J. Environ. Pollut.2004, 21, 211-222, https://doi.org/10.1504/IJEP.2004.004190.

20. Sharma, M.K.; Sobti, R.C. Rec effect of certain textile dyes in Bacillus subtilis. Mutat. Res. - Genet. Toxicol. Environ. Mutagen.2000, 465, 27-38, https://doi.org/10.1016/S1383-5718(99)00201-6.

21. Shen, D.; Fan, J.; Zhou, W.; Gao, B.; Yue, Q.; Kang, Q. Adsorption kinetics and isotherm of anionic dyes onto organo-bentonite from single and multisolute systems. J. Hazard. Mater.2009, 172, 99-107, https://doi.org/10.1016/j.jhazmat.2009.06.139.

22. Sulak, M.T.; Demirbas, E.; Kobya, M. Removal of Astrazon Yellow 7GL from aqueous solutions by adsorption onto wheat bran. Bioresour. Technol.2007, 98, 2590-2598, https://doi.org/10.1016/j.biortech.2006.09.010.

23. Yang, C.; Kheireddine, M.; Mohd, W.; Wan, A. Polyethyleneimine impregnation on activated carbon: Effects of impregnation amount and molecular number on textural characteristics and metal adsorption capacities. 2008, 112, 417-422, https://doi.org/10.1016/j.matchemphys.2008.05.075.

24. Afroze, S.; Sen, T.K. A Review on Heavy Metal Ions and Dye Adsorption from Water by Agricultural Solid Waste Adsorbents. Water. Air. Soil Pollut.2018, 229, https://doi.org/10.1007/s11270-018-3869-z.

25. Bhatti, H.N.; Jabeen, A.; Iqbal, M.; Noreen, S.; Naseem, Z. Adsorptive behavior of rice bran-based composites for malachite green dye: Isotherm, kinetic and thermodynamic studies. J. Mol. Liq.2017, 237, 322-333, https://doi.org/10.1016/j.molliq.2017.04.033.

26. Bhatti, H.N.; Safa, Y.; Yakout, S.M.; Shair, O.H.; Iqbal, M.; Nazir, A. Efficient removal of dyes using carboxymethyl cellulose/alginate/polyvinyl alcohol/rice husk composite: Adsorption/desorption, kinetics and recycling studies. International Journal of Biological Macromolecules 2020, 150, 861870,https://doi.org/10.1016/j.ijbiomac.2020.02.093.

27. Kanwal, A.; Bhatti, H.N.; Iqbal, M.; Noreen, S. Basic Dye Adsorption onto Clay/MnFe 2 O 4 Composite: A Mechanistic Study. Water Environ. Res.2017, 89, 301-311, https://doi.org/10.2175/106143017x14839994522984.

28. Fazal-ur-Rehman, M. Methodological trends in preparation of activated carbon from local sources and their impacts on production: a review. Chem. Int 2018, 4, 109-119, https://doi.org/10.31221/osf.io/5m7fp.

29. Yagub, M.T.; Sen, T.K.; Afroze, S.; Ang, H.M. Dye and its removal from aqueous solution by adsorption: A review. Adv. Colloid Interface Sci.2014, 209, 172-184, https://doi.org/10.1016/j.cis.2014.04.002.

30. Arshad, M.; Qayyum, A.; Shar, G.A.; Soomro, G.A.; Nazir, A.; Munir, B.; Iqbal, M. Zn-doped SiO2 nanoparticles preparation and characterization under the effect of various solvents: Antibacterial, antifungal and photocatlytic performance evaluation. J. Photochem. Photobiol. B Biol.2018, 185, 176-183, https://doi.org/10.1016/j.jphotobiol.2018.04.043.

31. Arshad, M.; Qayyum, A.; Abbas, G.; Haider, R.; Iqbal, M.; Nazir, A. Influence of different solvents on portrayal and photocatalytic activity of tin-doped zinc oxide nanoparticles. J. Mol. Liq.2018, 260, 272-278, https://doi.org/10.1016/j.molliq.2018.03.074.

32. Berradi, M.; Hsissou, R.; Khudhair, M.; Assouag, M.; Cherkaoui, O.; El Bachiri, A.; El Harfi, A. Textile finishing dyes and their impact on aquatic environs. Heliyon 2019, 5, https://doi.org/10.1016/j.heliyon.2019.e02711.

33. Ehsan, A.; Bhatti, H.N.; Iqbal, M.; Noreen, S. Native, acidic pre-treated and composite clay efficiency for the adsorption of dicationic dye in aqueous medium. Water Sci. Technol.2017, 75, 753-764, https://doi.org/10.2166/wst.2016.435. 
34. Hynes, N.R.J.; Kumar, J.S.; Kamyab, H.; Sujana, J.A.J.; Al-Khashman, O.A.; Kuslu, Y.; Ene, A.; Suresh Kumar, B. Modern enabling techniques and adsorbents based dye removal with sustainability concerns in textile industrial sector -A comprehensive review. J. Clean. Prod.2020, 272, 122636, https://doi.org/10.1016/j.jclepro.2020.122636.

35. Kausar, A.; Bhatti, H.N.; MacKinnon, G. Equilibrium, kinetic and thermodynamic studies on the removal of U(VI) by low cost agricultural waste. Colloids Surfaces B Biointerfaces2013, 111, 124-133, https://doi.org/10.1016/j.colsurfb.2013.05.028.

36. Kausar, A.; Bhatti, H.N.; Iqbal, M.; Ashraf, A. Batch versus column modes for the adsorption of radioactive metal onto rice husk waste: Conditions optimization through response surface methodology. Water Sci. Technol.2017, 76, 1035-1043, https://doi.org/10.2166/wst.2017.220.

37. Abdelwahab, O.; El Nemr, A.; El Sikaily, A.; Khaled, A. Use of rice husk for adsorption of direct dyes from aqueous solution: a case study of Direct F. Scarlet. Egyptian Journal of Aquatic Research 2005, 31, 1-11.

38. Altıntıg, E.; Altundag, H.; Tuzen, M.; Sarı, A.; Sar1, A. Effective removal of methylene blue from aqueous solutions using magnetic loaded activated carbon as novel adsorbent. Chem. Eng. Res. Des. 2017, 122, 151163, https://doi.org/10.1016/j.cherd.2017.03.035.

39. Özer, D.; Dursun, G.; Özer, A. Methylene blue adsorption from aqueous solution by dehydrated peanut hull. J. Hazard. Mater.2007, 144, 171-179, https://doi.org/10.1016/j.jhazmat.2006.09.092.

40. El Qada, E.N.; Allen, S.J.; Walker, G.M. Adsorption of basic dyes from aqueous solution onto activated carbons. Chem. Eng. J.2008, 135, 174-184, https://doi.org/10.1016/j.cej.2007.02.023.

41. Khan, R.; Bhawana, P.; Fulekar, M.H. Microbial decolorization and degradation of synthetic dyes: A review. Rev. Environ. Sci. Biotechnol.2013, 12, 75-97, https://doi.org/10.1007/s11157-012-9287-6.

42. Al-Futaisi, A.; Jamrah, A.; Al-Hanai, R. Aspects of cationic dye molecule adsorption to palygorskite. Desalination 2007, 214, 327-342, https://doi.org/10.1016/j.desal.2006.10.024.

43. Atar, N.; Olgun, A. Removal of basic and acid dyes from aqueous solutions by a waste containing boron impurity. Desalination 2009, 249, 109-115, https://doi.org/10.1016/j.desal.2008.12.045.

44. Eren, E.; Cubuk, O.; Ciftci, H.; Eren, B.; Caglar, B. Adsorption of basic dye from aqueous solutions by modified sepiolite: Equilibrium, kinetics and thermodynamics study. Desalination2010, 252, 88-96, https://doi.org/10.1016/j.desal.2009.10.020.

45. Eren, E.; Afsin, B. Investigation of a basic dye adsorption from aqueous solution onto raw and pre-treated sepiolite surfaces. Dye. Pigment.2007, 73, 162-167, https://doi.org/10.1016/j.dyepig.2005.11.004.

46. Eren, E.; Afsin, B. Investigation of a basic dye adsorption from aqueous solution onto raw and pre-treated bentonite surfaces. Dye. Pigment.2008, 76, 220-225, https://doi.org/10.1016/j.dyepig.2006.08.019.

47. Kannan, N.; Sundaram, M.M. Kinetics and mechanism of removal of methylene blue by adsorption on various carbons - A comparative study. Dye. Pigment.2001, 51, 25-40, https://doi.org/10.1016/S01437208(01)00056-0.

48. Oladoja, N.A.; Aboluwoye, C.O.; Oladimeji, Y.B.; Ashogbon, A.O.; Otemuyiwa, I.O. Studies on castor seed shell as a sorbent in basic dye contaminated wastewater remediation. Desalination 2008, 227, 190-203, https://doi.org/10.1016/j.desal.2007.06.025.

49. Ponnusami, V.; Gunasekar, V.; Srivastava, S.N. Kinetics of methylene blue removal from aqueous solution using gulmohar (Delonix regia) plant leaf powder: Multivariate regression analysis. J. Hazard. Mater.2009, 169, 119-127, https://doi.org/10.1016/j.jhazmat.2009.03.066.

50. Vadivelan, V.; Vasanth Kumar, K. Equilibrium, kinetics, mechanism, and process design for the sorption of methylene blue onto rice husk. J. Colloid Interface Sci.2005, 286, 90-100, https://doi.org/10.1016/j.jcis.2005.01.007.

51. Sivarajasekar, N.; Baskar, R. Agriculture waste biomass valorisation for cationic dyes sequestration: a concise review. J. Chem. Pharm. Res 2015, 7, 737-748.

52. Dannenberg J.J. Synthetic Applications of 1,3-Dipolar Cycloaddition Chemistry toward Heterocycles and Natural Products. Book reviews. 1998, 123, 1009-1011.

53. Attia, A.A.; Rashwan, W.E.; Khedr, S.A. Capacity of activated carbon in the removal of acid dyes subsequent to its thermal treatment. Dye. Pigment.2006, 69, 128-136, https://doi.org/10.1016/j.dyepig.2004.07.009.

54. Qin, Q.; Ma, J.; Liu, K. Adsorption of anionic dyes on ammonium-functionalized MCM-41. J. Hazard. Mater.2009, 162, 133-139, https://doi.org/10.1016/j.jhazmat.2008.05.016.

55. Tabak, A.; Eren, E.; Afsin, B.; Caglar, B. Determination of adsorptive properties of a Turkish Sepiolite for removal of Reactive Blue 15 anionic dye from aqueous solutions. J. Hazard. Mater.2009, 161, 1087-1094, https://doi.org/10.1016/j.jhazmat.2008.04.062.

56. Abdullah, M.O.; Tan, I.A.W.; Lim, L.S. Automobile adsorption air-conditioning system using oil palm biomass-based activated carbon: A review. Renew. Sustain. Energy Rev.2011, 15, 2061-2072, https://doi.org/10.1016/j.rser.2011.01.012.

57. Dąbrowski, A. Adsorption-From theory to practice. Adv. Colloid Interface Sci.2001, 93, 135-224, https://doi.org/10.1016/S0001-8686(00)00082-8.

58. Corapcioglu, M.O.; Huang, C.P. The surface acidity and characterization of some commercial activated carbons. Carbon N. Y.1987, 25, 569-578, https://doi.org/10.1016/0008-6223(87)90200-4. 
59. Acevedo, B.; Barriocanal, C. Texture and surface chemistry of activated carbons obtained from tyre wastes. Fuel Process. Technol.2015, 134, 275-283, https://doi.org/10.1016/j.fuproc.2015.02.009.

60. Chuah, T.G.; Jumasiah, A.; Azni, I.; Katayon, S.; Choong, S.Y.T. Rice husk as a potentially low-cost biosorbent for heavy metal and dye removal: an overview. 2005, 175, 305-316, https://doi.org/10.1016/j.desal.2004.10.014.

61. Nageeb, M. Adsorption Technique for the Removal of Organic Pollutants from Water and Wastewater. Org. Pollut. - Monit. Risk Treat.2013, https://doi.org/10.5772/54048.

62. Najm, I.N.; Snoeyink, V.L.; Lykins, B.W.; Adams, J.Q. Using Powdered Activated Carbon: A Critical Review. J. Am. Water Works Assoc. 1991, 83, 65-76, https://doi.org/10.1002/j.1551-8833.1991.tb07087.x.

63. Noroozi, B.; Sorial, G.A.; Bahrami, H.; Arami, M. Equilibrium and kinetic adsorption study of a cationic dye by a natural adsorbent - Silkworm pupa. 2007, 139, 167-174, https://doi.org/10.1016/j.jhazmat.2006.06.021.

64. Wohl, H. Book Reviews: Book Reviews. Blood 1972, 40, 148-149.

65. Xie, K.; Zhao, W.; He, X. Adsorption properties of nano-cellulose hybrid containing polyhedral oligomeric silsesquioxane and removal of reactive dyes from aqueous solution. Carbohydr. Polym.2011, 83, 1516-1520, https://doi.org/10.1016/j.carbpol.2010.09.064.

66. Armbruster, M.H.; Austin, J.B. The Adsorption of Gases on Plane Surfaces of Mica. J. Am. Chem. Soc.1938, 60, 467-475, https://doi.org/10.1021/ja01269a066.

67. El-Zahhar, A.A.; Awwad, N.S. Removal of malachite green dye from aqueous solutions using organically modified hydroxyapatite. J. Environ. Chem. Eng.2016, 4, 633-638, https://doi.org/10.1016/j.jece.2015.12.014.

68. Febrianto, J.; Kosasih, A.N.; Sunarso, J.; Ju, Y.H.; Indraswati, N.; Ismadji, S. Equilibrium and kinetic studies in adsorption of heavy metals using biosorbent: A summary of recent studies. J. Hazard. Mater. 2009, 162, 616-645, https://doi.org/10.1016/j.jhazmat.2008.06.042.

69. Park, D.; Yun, Y.S.; Park, J.M. The past, present, and future trends of biosorption. Biotechnol. Bioprocess Eng. 2010, 15, 86-102, https://doi.org/10.1007/s12257-009-0199-4.

70. Doke, K.M.; Khan, E.M. Adsorption thermodynamics to clean up wastewater; critical review. Rev. Environ. Sci. Biotechnol.2013, 12, 25-44, https://doi.org/10.1007/s11157-012-9273-z.

71. Samarghandy, M.R.; Hoseinzade, E.; Taghavi, M.; Hoseinzadeh, S. Biosorption of reactive black 5 from aqueous solution using acid-treated biomass from potato peel waste. BioResources2011, 6, 4840-4855.

72. Gupta, N.; Kushwaha, A.K.; Chattopadhyaya, M.C. Application of potato (Solanum tuberosum) plant wastes for the removal of methylene blue and malachite green dye from aqueous solution. Arab. J. Chem.2016, 9, S707-S716, https://doi.org/10.1016/j.arabjc.2011.07.021.

73. Maleki, A.; Daraei, H.; Khodaei, F.; Bayazid-Aghdam, K.; Rezaee, R.; Naghizadeh, A. Investigation of potato peel-based bio-sorbent efficiency in reactive dye removal: Artificial neural network modeling and genetic algorithms optimization. J Adv Env. Heal. Res2013, 1, 21-29, https://dx.doi.org/10.22102/jaehr.2013.40121.

74. Moubarak, F.; Atmani, R.; Maghri, I.; Elkouali, M.; Talbi, M.; Bouamrani, M.L.; Salouhi, M.; Kenz; Abdelkbir Elimination of Methylene Blue Dye with NaturalAdsorbent « Banana Peels Powder ». Glob. J. Sci. Front. Res. B Chem.2014, 14.

75. Liu, R.L.; Liu, Y.; Zhou, X.Y.; Zhang, Z.Q.; Zhang, J.; Dang, F.Q. Biomass-derived highly porous functional carbon fabricated by using a free-standing template for efficient removal of methylene blue. Bioresour. Technol.2014, 154, 138-147, https://doi.org/10.1016/j.biortech.2013.12.034.

76. Amel, K.; Hassen, M.A.; Kerroum, D. Isotherm and kinetics study of biosorption of cationic dye onto banana peel. Energy Procedia2012, 19, 286-295, https://doi.org/10.1016/j.egypro.2012.05.208.

77. Pishgar, M.; Yazdanshenas, M.E.; Ghorbani, M.H.; Farizadeh, K. Removal of Basic Blue 159 from Aqueous Solution Using Banana Peel as a Low-Cost Adsorbent. J. Appl. Chem. Res.2013, 7, 51-62.

78. Ahmad, M.A.; Alrozi, R. Removal of malachite green dye from aqueous solution using rambutan peel-based activated carbon: Equilibrium, kinetic and thermodynamic studies. Chem. Eng. J.2011, 171, 510-516, https://doi.org/10.1016/j.cej.2011.04.018.

79. Alrozi, R.; Zamanhuri, N.A.; Osman, M.S.; Adsorbate, A. Adsorption of reactive dye Remazol Brilliant Blue $\mathrm{R}$ from aqueous solutions by rambutan peel. Proceedings of the 2012 IEEE Symposium on Humanities, Science and Engineering Research2012, 21-26.

80. Njoku, V.O.; Foo, K.Y.; Asif, M.; Hameed, B.H. Preparation of activated carbons from rambutan (Nephelium lappaceum) peel by microwave-induced $\mathrm{KOH}$ activation for acid yellow 17 dye adsorption. Chemical Engineering Journal 2014, 250, 198-204,https://doi.org/10.1016/j.cej.2014.03.115.

81. Akkaya, G.; Güzel, F. Application of Some Domestic Wastes As New Low-Cost Biosorbents for Removal of Methylene Blue: Kinetic and Equilibrium Studies. Chem. Eng. Commun.2014, 201, 557-578, https://doi.org/10.1080/00986445.2013.780166.

82. Jayarajan, M.; Arunachala, R.; Annadurai, G. Use of Low Cost Nano-porous Materials of Pomelo Fruit Peel Wastes in Removal of Textile Dye. Res. J. Environ. Sci.2011, 5, 434-443, https://doi.org/10.3923/rjes.2011.434.443.

83. Argun, M.E.; Güclü, D.; Karatas, M. Adsorption of Reactive Blue 114 dye by using a new adsorbent: Pomelo peel. J. Ind. Eng. Chem.2014, 20, 1079-1084, https://doi.org/10.1016/j.jiec.2013.06.045. 
84. El-Said, A.G.; Gamal, A.M.; Mansour, H.F. Potential Application of Orange Peel as an Eco-friendly Adsorbent for Textile Dyeing Effluents. Res. J. Text. Appar.2013, 17, 31-39, https://doi.org/10.1108/RJTA17-04-2013-B004.

85. Khalfaoui, A.; Bendjamaa, I.; Bensid, T.; Meniai, A.H.; Derbal, K. Effect of calcination on orange peels characteristics: Application of an industrial dye adsorption. Chem. Eng. Trans.2014, 38, 361-366, https://doi.org/10.3303/CET1438061.

86. Ahmed, S.A.S.; Khalil, L.B.; Nabarawy, E.I. Removal of reactive Blue 19 dye from aqueous solution using natural and modified Orange peel. Cabon Lett.2012, 13, 212-220, http://dx.doi.org/10.5714/CL.2012.13.4.212. 